
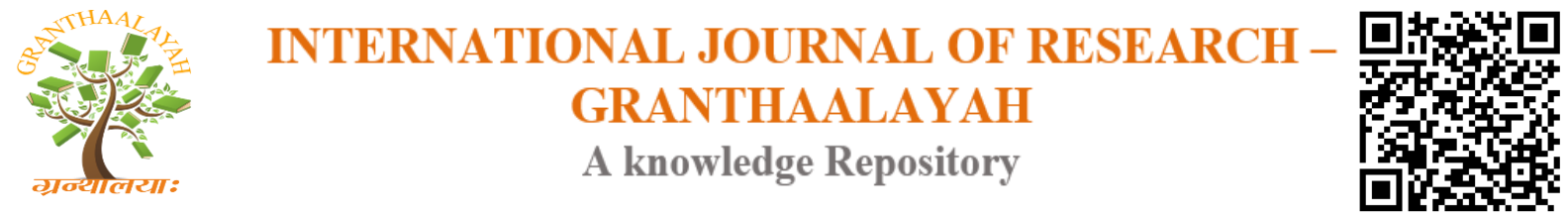

Management

\title{
DETERMINANTS OF REAL EXCHANGE RATE IN ETHIOPIA
}

\author{
Dr. P.Nandeeswara Rao ${ }^{1}$, Tassew Dufera Tolcha ${ }^{2}$ \\ ${ }^{1,2}$ Department of Economics, Hawassa University, Hawassa, ETHIOPIA
}

DOI: https://doi.org/10.29121/granthaalayah.v4.i6.2016.2652

\section{ABSTRACT}

Real exchange rate has direct effects on trade particularly on international trade and has indirect effects on productions and employments, so it is crucial to understand the factors which determine its variations. This study analyses the main determinants of the real exchange rate and the dynamic adjustment of the real exchange rate following shocks to those determinants using yearly Ethiopian time series data covering the period 1971 to 2010 . It begins with a review of literatures on Exchange rate, real exchange rate, determinants of the real exchange rate and provides an updated background on the exchange rate system in Ethiopia. An empirical model linking the real exchange rate to its theoretical determinants is then specified. This study had employed the cointegration and vector autoregression (VAR) analysis with impulse response and variance decomposition analyses to provide robust long run effects and short run dynamic effects on the real exchange rate.

Share of investment, foreign exchange reserve, capital inflow and government consumption of non-tradable goods were the variable that have been found to have a long run relationship with the real exchange rate. The estimate of the speed of adjustment coefficient found in this study indicates that about a third of the variation in the real exchange rate from its equilibrium level is corrected within a year.

The regression result of VECM reveals that terms of trade, nominal exchange rate, and one period lag of capital flow were the variables significantly affects the real exchange rate in the short run. However, the impulse response and variance decomposition analysis shows a better picture of the short run dynamics. The their analysis provided evidence that the Shocks to terms of trade, nominal exchange rate, capital inflow and share of investment have persistent effects on the real exchange rate in the short run. In general the regression results of both long run and short run models mostly suggest that the fluctuations of real exchange rates are predominantly responses to monetary policies shocks rather than fiscal policy shocks.

Keywords:

Exchange Rate, Ethiopian, Cointegration, Vector Autoregression.

Cite This Article: Dr. P.Nandeeswara Rao, and Tassew Dufera Tolcha, "DETERMINANTS OF REAL EXCHANGE RATE IN ETHIOPIA" International Journal of Research - Granthaalayah, Vol. 4, No. 6 (2016): 183-210. 


\section{INTRODUCTION}

The Ethiopian birr was pegged to the United States dollar (USD) from its beginning in 1945 until the early 1990s. The birr was valued at 2.48 per USD on July 23, 1945 and after two decades, that is, on January 1, 1964; the Ethiopian birr was slightly devalued to 2.50 per US dollar before the collapse of the Bretton Woods system in 1971, which forced an initial overvaluation to 2.30. Then in 1973 the birr overvalued to 2.07 per USD. After the fall of Derg regime in 1992 the transitional government devalued the birr to 5.00 per USD, and several (smaller) devaluations followed. Auction-based exchange rate system was introduced in 1993 and in October 2001 foreign exchange interbank market was established (Geda, 2006).

The exchange rate provides a key link between a country and the rest of the world, both in goods and assets markets. It affects the volume of both imports and exports (by changing their relative prices), as well as the stock of foreign debt in domestic currency terms (Afridi, 1996). In fact, all transactions with the rest of the world can be potentially affected by the level of the exchange rate. A depreciation of exchange rate is often associated with competitiveness gains, in a sense relative price of export will fall and imports become relatively more expensive. However currency depreciation usually worsens the country's debt position and increase interest payments (Martins, 2009). Poor exchange rate policy risks misrepresenting trade opportunities resulting in misallocation of resources. A competitive and stable real exchange rate (RER) should be the optimal policy target.

Since the real exchange rate reveals the relative competitiveness of the exported goods from the domestic economy to the rest of the world, it is desirable to characterize its behavior and test its fundamental determinants. Because of its importance, the RER has therefore been given a prominent role in the adjustment programs supported by the International Monetary Fund (IMF). It has also been argued that the RER not only affects general economic performance and international competitiveness, but also different sectors of the economy, foreign trade flows, balance of payments, external debt crisis, employment, structure of production, consumption and allocation of resources in the economy. Therefore, RER stability works to stabilize all these sectors.

\section{STATEMENT OF THE PROBLEM}

Among the factors that contribute for the poor performance of the Ethiopian economy in general and that of the export sector in particular during Derg Regime, was the overvalued exchange rate of the birr (Geda, 2006). Overvaluation of the exchange rate causes misallocation of resources in production and promotes investment of resources in rent-seeking and socially unproductive but privately profitable activities which reduces the growth rate of output. Additionally overvaluation of exchange rate stagnates the export sector and promotes imports of foreign country's products which results in deficit trade balance of the country. In line with this argument, Stefan Dercon and Lulseged Ayalew (1994) attested that overvaluation of Ethiopian birr also reduced the competitiveness of legal exports and led to significant smuggling.

On the other hand the current government took gradual devaluation of birr at different times to overcome the negative impacts of exchange rate overvaluation on the economy of the country in 
general. In addition to devaluation different system of determining exchange rate were adopted to increase the competitiveness of Ethiopia on world export markets. These system includes auction exchange rate introduced in 1993, in 1995 the unification of official and auction based exchange rate was in operation, in October 2001, a foreign exchange interbank market was established and currently the exchange rate is determined through an interbank foreign exchange market on a daily basis.

Despite different measures were adopted in both regimes (Derg and EPRDF), the real exchange rate of the country is still deteriorating through time. A real exchange rate index has often been used to determine the appropriateness of an exchange rate policy. In the context of this paper real effective exchange rate is synonymous with real exchange rate. As defined by Edward (1989), to obtain the real exchange indexes the relevant way is real effective exchange rate. Following Edward's (1989) definition, an increase in the value of real exchange rate implies real depreciation whereas a fall implies real appreciation of domestic currency, which in turn implies loss of competitiveness of a country in the world export market.

On the hand the gap between nominal exchange rate and real exchange rate is diverging through time. Different measures were undertaken in different regimes but the difference is not minimized yet. The loss of competitiveness in world export market will continue unless deterioration of real exchange rate is improved at some point. We understand from the past experience that making an adjustment only on nominal exchange rate did not improve the real exchange rate of the country. Therefore in addition to nominal exchange rate other major determinants of real exchange rate should be examined. To set the optimal real exchange rate, the directions and strength of these determinants should be known.

The apparent shift in exchange rate policy to boost export performance and promotes surplus trade balance raises the question of what strategy the government will now follow to maintain macroeconomic stability. In Ethiopia's case, where price stability, economic growth and export competitiveness are all concerns, it is useful to consider the issue in terms of the monetary conditions particularly exchange rate. Given the international ramifications of using exchange rate policies to address competitiveness issues, it would be highly useful for Ethiopia to establish a benchmark for what might be determining a fair valuation of the birr.

Generally, this paper tries to identify determinants for deterioration of real exchange rate in Ethiopia and what might be determining the fair valuation of birr. Having these benchmarks for the exchange rate changes, then we are in a position to choose an appropriate policy mix.

\section{OBJECTIVE OF THE STUDY}

The primary objective of this paper is to examine the determinants of real exchange rate of the country.

The specific objectives of the study are:-

- To investigate the short run and long run determinants of real exchange rate in Ethiopia.

- To show the direction and influential power of the variables in the model.

- To contribute the empirical literature of real exchange rate in Ethiopia

- To indicate some possible policy implications. 


\section{HYPOTHESIS TO BE TESTED}

Based on economic theory and empirical literature on exchange rate in the country, we propose the following relationships to hold true in our analysis.

- Share of investment appreciates the real exchange rate in the long-run.

- Terms of trade have positive impact (appreciation) on the real exchange rate.

- An increase in central bank reserves appreciates the real exchange rate.

- Large capital inflow improves the real exchange rate appreciation.

The validity of all these statements will be investigated in the fourth section of the paper.

\section{LITERATURE REVIEW}

The central focus for analyzing of the determinants of the real exchange rate and the effects of real exchange rate misalignment is the desire to determine an appropriate concept of equilibrium exchange rate and to estimate its value. Since the real exchange rate reveals the relative competitiveness of the exported goods from the domestic economy to the rest of the world, it is desirable to characterize its behavior and test its fundamental determinants. Different economists develop various models to identify theoretically potential determinants of real exchange rate. Additionally, they come up with some empirical evidences and found the determinants of real exchange rate for different case studies. The aim of this chapter is revising these theoretical and empirical backgrounds of real exchange rate to underlay the fertile ground for upcoming analysis. In the first section of this review the theoretical back ground including definitions of real exchange rate, its type, views of different economic thoughts, different methods of measuring exchange rate particularly real exchange rate and the like concepts will be presented. In proceeding section of empirical reviews the works of different researchers, evolution of exchange rate management in Ethiopia, the exchange rate regimes in Ethiopia and other related ideas will be revised.

\section{PRELIMINARY CONCEPTS}

Before directly go to real exchange rate in detail, let's have a bird view over the conceptual framework of exchange rate and exchange rate markets. Without understanding the basic structure of exchange rate there are both conceptual and empirical difficulties in the measurement of the real exchange rate. There are also several definitions of both the nominal and real exchange rate, which are based on different analytical frameworks used for different purposes.

The foreign exchange rate is one of the most important prices in an open economy. It is the price of one currency in terms of another or it is simply the rate at which currencies are exchanged. In other words, it links the domestic economy with the rest of the world through both the goods and assets markets. There are two broad categories of exchange rate, namely, spot and forward exchange rate (MacDonald, 2007). Spot exchange rate is the rate at which foreign exchange can be bought and sold for immediate delivery, conventionally one or two days. On the other hand forward exchange rate is the rate negotiated today at which foreign exchange can be bought and sold for delivery sometime in the future. The most popularly traded forward contract has a 
maturity of 90 days and contracts beyond one year are relatively scarce. Since spot exchange rate is the widely used type we go further through it. We have also two major types of spot exchange rate, nominal and real. Both nominal and real exchange rates have their respective divisions. The general framework of exchange rate is explained in the following diagram.

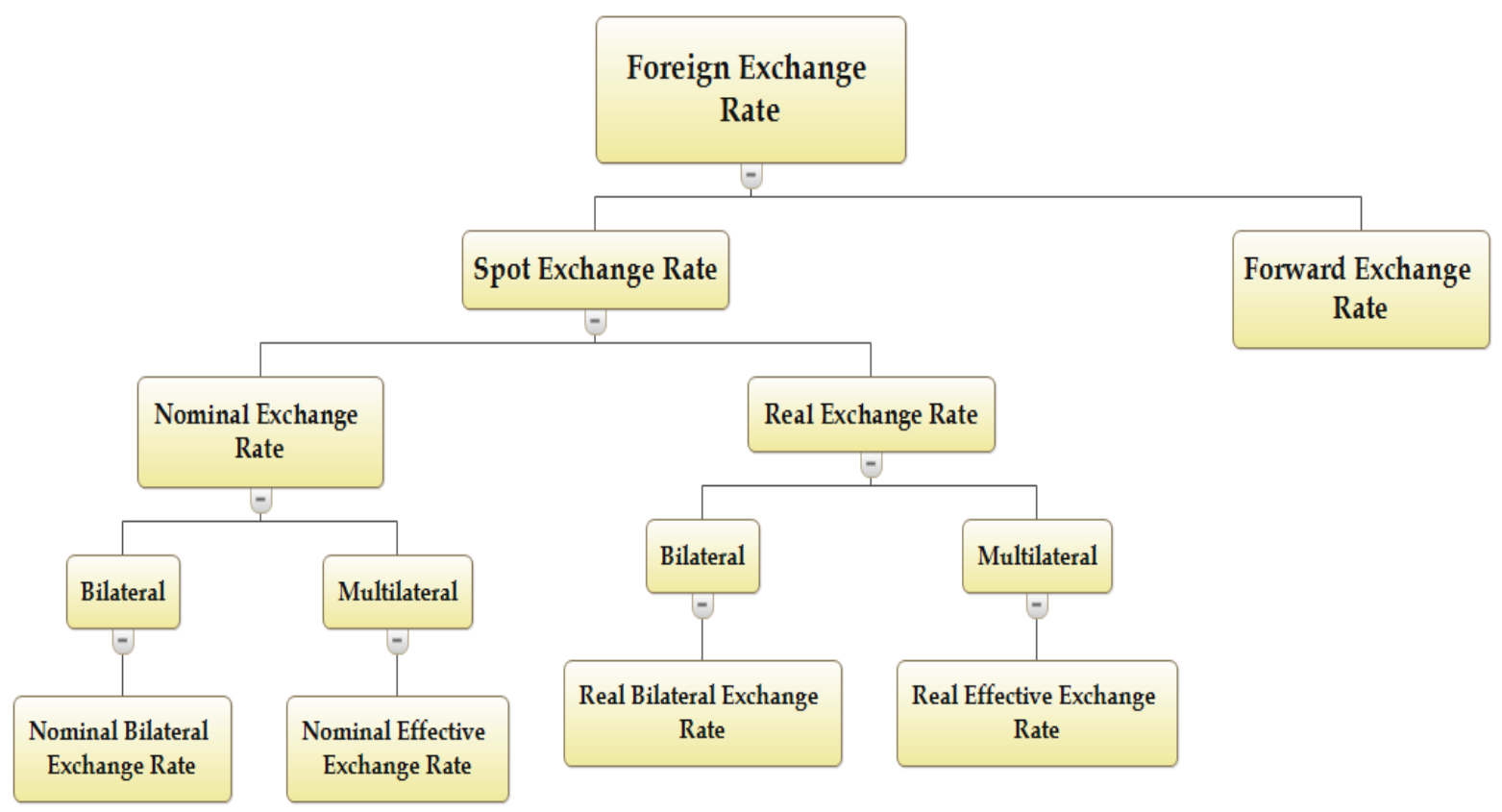

Figure 2.1: A simple conceptual framework of the exchange rate.

\section{EXCHANGE RATE SYSTEMS IN ETHIOPIA}

Modern banking in Ethiopia was started in 1905 with the establishment of Abyssinian Bank which was based on a fifty year agreement with the Anglo-Egyptian National Bank. In 1908 a new development bank (called Societe Nationale d'Ethiope Pour le Development del'Agriculture et du Commerce) and two other foreign banks (Banque de l'Indochine and the Compagnie de l'Afrique Orientale) were also established (Pankhrust 1968 cited in Degefe 1995). These banks were criticized for being wholly foreign owned. In 1931 the Ethiopian government purchased the Abyssinian Bank, which was the dominant bank and renamed it the Bank of Ethiopia, the first nationally owned bank on the African continent (Gedey, 1990). Further financial institutions were established during the Italian occupations of the late 1930s. In 1943 the Ethiopian government established the State Bank of Ethiopia which was operating both as commercial and a central bank until 1963 when it was remodeled into today's National Bank of Ethiopia. After this period many other banks were established and just before the 1974 revolution about ten banks were in operation (Gedey, 1990).

All privately owned financial institutions were nationalized on 1 January 1975 . The nationalized banks were reorganized and one commercial bank (the Commercial Bank of Ethiopia), a national bank, two specialized banks, the Agricultural and Industrial Bank (AIB), renamed recently as the Development Bank of Ethiopia (DBE) and a Housing and Saving Bank (HSB), renamed recently as the Construction and Business Bank (CBB), and one insurance company (Ethiopian Insurance 
Company),were formed. Following the regime change in 1991 and the liberalization policy in 1992, these financial institutions were reorganized to work to a market-oriented policy framework. Moreover, new privately owned financial institutions were also allowed to work alongside the publicly owned ones (Geda, 2006).

During these evolutions of financial sectors in Ethiopia, different exchange rate policies were adopted in different regimes. The aim of this chapter is to provide a brief overview of the exchange rate regimes that Ethiopia has had during these periods and the evolution of the real exchange rate in those different regimes. Edwards (1989) shows that nominal exchange rate policy can be both a cause of and a tool for correcting misalignment in the real exchange rate. The importance of nominal exchange rate regimes that Ethiopia has had cannot therefore be underestimated when analyzing the determinants of real exchange rate. In addition, knowledge of these regime shifts may assist in explaining structural breaks that may be observed in the data which is important for modeling the real exchange rate. These policies were adjusted with political ideology of the regimes. The rest of this chapter tries to examine the exchange rate policies adopted during emperor, Derg and post reform regimes.

\section{PRE-REFORM EXCHANGE RATE SYSTEMS}

This period covers both the Imperial and Derg regimes. The legal currency of Ethiopia was issued on $23^{\text {rd }}$ July 1945 by defining the monetary unit as the Ethiopia dollar (renamed as Ethiopian birr in September 1976) with a value of 0.36 grams of fine gold Degefa (2001). The linkage with fine gold was in accordance with the monetary system established by the Bretton Woods Agreement of 1944 which established the exchange rate between the national currency and other currencies with the same arrangement. Accordingly the official exchange rate of Ethiopian currency was 2.48 birr per US dollar on July 23, 1945. This fixed exchange rate was under operation for almost two decades. On January 1, 1964 the Ethiopian dollar was slightly devalued to 2.50 birr per US dollar. Following the collapse of the Bretton Woods System in 1971, the Ethiopian dollar was revalued to 2.30 birr per US dollar on $21^{\text {st }}$ December 1971 . The subsequent $10 \%$ devaluation of the US dollar had temporarily brought about undervaluation of the birr. To realign the Ethiopian birr, it was again revalued to 2.07 Ethiopian dollars per US dollar in February 1973. From then on, the Ethiopian currency was pegged to the US dollar at the rate of 2.07 birr per dollar until massive devaluation of October 1992. This fixed official exchange rate was left unaltered for two decades despite the floating of the major world currencies including the US dollar. In effect the birr became over-valued in terms of the US dollar as well as many other foreign currencies. According to Haile Kibret (1994), the real exchange rate is consistently higher than the nominal exchange rate which implies that the Ethiopian birr has been over-valued since the mid-1970s. The over-valuation of the birr may be followed by the continuous appreciation in real official exchange rate prior to huge devaluation of the birr in October 1992.

\section{POST-REFORM EXCHANGE RATE SYSTEM (1991- TO DATE)}

Following the overthrown of Derg regime, EPRDF introduced the auction-based exchange rate determination scheme and the interbank money market. Additionally the principle of gradualism in liberalization of exchange rate market is at the heart of this policy development. The exchange 
rate reform was started by devaluing the currency which was fixed for about two decades to 2.07 birr per US dollar by $140 \%$ to 5 birr per US dollar in October 1992. In 1993 the NBE introduced the auction-based exchange rate system. It was conducted on a fortnightly basis and took the form of discriminatory price which clears the market for the coming two weeks. The supply of funds for this market was obtained from export earnings, loans and grants. The auction-based exchange rate system was initially worked side by side with the official exchange rate. The system was supervised by a committee composed of the NBE, Ministry of Finance, Ministry of Economic Development and External Cooperation and two representatives from the private sectors. Before the unification of official exchange rate and auction-based exchange rate systems August 1995, the official exchange rate was used for import of fertilizer, petroleum, pharmaceutical products, Ethiopia's contribution to international organizations and external debt service payments. In July 1996 the NBE introduced a weekly auction replacing the previous auction system. The NBE also replaced the retail auction system by a wholesale auction system where banks are considered as wholesale bidders.

In 1998 The NBE issued directives aimed at establishing interbank foreign exchange and money markets. The interbank foreign exchange market (IBFEM) is a wholesale market, where the amount traded is large and the spread between buying and selling rates is narrower than the normal situation for commercial transactions. It is an exclusive market for banks to trade foreign exchange with each other. The establishment of this market is primarily motivated by the recognition that the foreign exchange supply by NBE through the auction system is not sufficient to satisfy the demand of banks. Currently the exchange rate is determined through an interbank foreign exchange market on a daily basis, a clear indication of the government's policy of gradualism toward liberalizing the exchange rate market.

Generally the following table will summarize the main events happened concerning exchange rate system evolution in Ethiopia. The table summarizes the major events at specified period of time.

Table 2.1: A Summary of exchange rate policy in Ethiopia

\begin{tabular}{|l|l|}
\hline Period & Exchange rate policy and value of birr \\
\hline 1945 & $\begin{array}{l}\text { The legal currency of Ethiopia was issued as Ethiopian dollar. The official exchange } \\
\text { rate of Ethiopian currency was } 2.48 \text { birr per US dollar which equals with 0.36 gram } \\
\text { fine gold. } \\
\text { The Ethiopian dollar was devalued to } 2.50 \text { birr per US dollar. } \\
\text { The Ethiopian dollar was revalued to } 2.30 \text { birr per US dollar. } \\
\text { The Ethiopian currency was pegged to the US dollar at the rate of } 2.07 \text { birr per dollar. } \\
1964 \\
1973\end{array}$ \\
1992 & $\begin{array}{l}\text { Introduction of the auction-based exchange rate system to Ethiopian financial market. } \\
\text { The value of birr was } 5 \text { birr per Us dollar. }\end{array}$ \\
1993 & $\begin{array}{l}\text { Unification of official exchange rate and auction-based exchange rate systems. The } \\
\text { Ethiopian birr was valued at } 6.25 \text { per Us dollar. } \\
\text { Establishment of interbank foreign exchange and money markets. The exchange rate } \\
\text { was } 6.88 \text { per US dollar. } \\
\text { Introduction of daily Interbank Market. In this year the average exchange rate was } \\
8.53 \text { per US dollar. } \\
\text { Devaluation of birr from 13.63 to 16.35 per US dollar. }\end{array}$ \\
2001 &
\end{tabular}




\section{METHODOLOGY, DATA SOURCES AND MODEL SPECIFICATION}

\section{DATA AND METHODOLOGY Sources of Data}

In this paper time series data from 1971 to 2010 will be used for the investigation. The major sources of data for the study are World Bank and International Monetary Funds. From the World Bank world development indicators and African development indicators are the specific sources. Yearbooks released in different years and International Financial Statistics are specific data sources in IMF. Effort will be exerted to fill the missing values using alternative sources like National Bank of Ethiopia, Ministry of Finance and Development, Central Statistical Agency and Ethiopian Economic Association.

\section{Framework for deriving the real exchange rate Model}

The path of real exchange rate in small open economy like Ethiopia may be determined by the following variables:

Terms of trade (TOT): Terms of trade describes the effects of external demand and supply on the domestic tradable goods sector. In other words the effect of the terms of trade on the real exchange rate operates through import and export price variations. The impact of a change in the terms of trade on the real exchange rate is theoretically ambiguous (Edward, 1989). It depends on the relative strength of the income and substitution effects, which emerge from changes in the prices of both imports and exports. If the direct income effect dominates the indirect substitution effect following an increase in the price of exports relative to imports (an improvement in the terms of trade), the real exchange rate will appreciate. TOT can be represented as relative price of exports to imports.

$$
\text { TOT }=\frac{P_{x}}{P_{m}}
$$

Where, TOT - terms of trade, $\mathrm{P}_{\mathrm{x}}-$ foreign prices of exports, $\mathrm{P}_{\mathrm{m}}-$ foreign prices of imports

Government consumption of non-tradable goods: The impact of government consumption on the real exchange rate depends on whether such spending is predominantly on tradable goods or on nontradable goods. An increase in government spending on tradable goods creates a trade deficit, which requires a real depreciation in the exchange rate in order to maintain external balance. Data on consumption on nontradable is not easily available. Thus, in this paper government consumption of nontradable goods is proxied by the ratio of total government consumption to gross domestic product.

$$
G C_{n}=\frac{G C}{G D P}
$$

Where, $\mathrm{GC}_{\mathrm{n}}$-government consumption of nontradable goods $\mathrm{GC}$ - government consumption, GDP - gross domestic product

Foreign exchange reserves: Indicates the capacity of the national bank to defend the domestic currency. An improvement in the stock of foreign exchange reserves is theoretically expected to appreciate the real exchange rate. An increase in reserves has the effect of appreciating the real exchange rate, while a decrease in reserves depreciates the real exchange rate. 
Share of investment: Its effects on the real exchange rate depend on whether an increase in investment changes the composition of spending on traded and non-traded goods. If an increase in share of investment to GDP increases spending on tradable goods, it would lead to the depreciation of real exchange rate. On the other hand, a change towards nontraded goods appreciates the real exchange rate.

Share of investment can be represented as the ratio of total investment to GDP.

$$
S I=\frac{T I}{G D P}
$$

Where, SI - share of investment, $\quad \mathrm{TI}$ - total investments

Capital inflow: Changes in the level of international transfers received by the domestic economies have an impact on the real exchange rate. An increase in capital inflows permits an expansion of absorption and consequently an appreciation of the real exchange rate.

Nominal Exchange rate: Theoretically nominal revaluation or appreciation of the nominal exchange rate appreciates the real exchange rate. A change in the nominal exchange rate can affect the real exchange rate if prices are slow to respond (Joyce and Kamas, 2003). Peter (2006) finds that the coefficient of a variable representing nominal devaluation is quite large, providing evidence to support the view that nominal devaluations can be a powerful tool to manage the real exchange rate.

Based on these theoretical background and data availability, this study estimates the following relationships:

$$
L R E R_{t}=\beta_{0}+\beta_{1} L T O T_{t}+\beta_{2} L G C_{n_{t}}+\beta_{3} L F E R_{t}+\beta_{4} L S I_{t}+\beta_{5} L C I_{t}+\beta_{8} L N E R_{t}+\mu_{t}
$$

Where the following notation has been used:

$L R E R_{t}$ - Natural log of real exchange rate,

$L T O T_{t}$ - Natural log of the terms of trade,

$L G C_{n_{t}}$ - Natural log of government consumption of nontradables,

$L F E R_{t}-$ Natural log of Foreign exchange reserves,

$L S I_{t} \quad$ - Natural log of share of investment,

$L C I_{t} \quad$ - Natural log of capital inflow,

$L N E R_{t}-$ Natural log of Nominal Exchange rate and

$\mu_{t}-$ Error term.

The implementation of this real exchange rate model may face problems due to the unavailability of time series data for some of the potential determinants. This mean such variable will either drop from the equation or alternatively, proxies for them have to be found.

\section{Methodology: Introduction}

In time series data analysis there are several techniques of parameter estimations including classical regression methods and cointegration based techniques. A classical regression method is based on the assumption that all the variables to be included in a regression are stationary. But most macroeconomic variables are non-stationary at level such that estimations based on this 
technique will be leads to spurious regression. Non stationary variables may be become stationary through differencing the variables. But such procedure gives only short run dynamics by eliminating long run information. These problems gave birth to a new generation of models based on cointegration and error correction models. There are also several cointegration based methods, but the majority of them suffer from numerous problems when applied to multivariate models. The technique in this category that has emerged as the most powerful and popular is the Johansen technique, which is the technique employed in this study.

\section{Testing for Stationarity}

Stationary series can be defined as one with a constant mean, constant variance and constant autocovariances for each given lag and the value of the covariance between the two time periods depends only on the distance or lag between the two time periods, not on the time at which the covariance is calculated (Gujarati, 2003). Otherwise it is non-stationary time series variable. But the interesting property of the non-stationary time series variable is that its difference can be made it stationary. In general, a non-stationary time series which has to be differenced $d$ times to make it stationary is said to be integrated of order $d$. The order of integration refers to the number of unit roots in the series, or the number of differencing operations it takes to make a variable stationary.

Brooks (2008) shows that if the dependent variable is a function of non-stationary variables, the regression will produce spurious results (a nonsense regression). Even though the trending variables are completely unrelated, it is likely that significant $t$-ratios and a high $\mathrm{R}^{2}$ will be obtained. Thus, to avoid the problem of spurious regression it is necessary to test for stationary of time series variables before running any sort of regression analysis. There are several tests for stationarity including a visual plot of the data, unit root tests and those that directly test for stationarity. Among these, unit root test specifically augmented Dickey-Fuller will be performed in this paper.

\section{Dickey-Fuller and the Augmented Dickey-Fuller Tests}

Presence of unit roots of the variables can be examined by Dickey-Fuller (DF) and Augmented Dickey-Fuller (ADF), which are the most frequently used unit root tests. The DF test estimates the following equation:-

$$
\Delta y_{t}=\delta+\beta t+\alpha y_{t-1}+\varepsilon_{t}
$$

Where, $y_{t}$ is the relevant time series variable, $\Delta$ is a first difference operator, $t$ is a linear trend and $\varepsilon_{t}$ is the error term. The error term should satisfy the assumptions of normality, constant error variance and independent (uncorrelated) error terms. DF test does not take into account the possible autocorrelation in the error term $\left(\varepsilon_{t}\right)$. The ADF test corrects this shortfall for high-order serial correlation by adding a lagged differenced term on the right-hand side in the DF equation (6). ADF employs the following equation:-

$$
\Delta y_{t}=\delta+\beta t+\alpha y_{t-1}+\sum_{i=2}^{m} \Delta y_{t-i} \varepsilon_{t}
$$


Both DF and ADF can also be estimated without including a constant and trend term.

The null hypothesis is that there exists a unit root in the time series (non-stationary time series), Ho: $\alpha=0$ against the alternative hypothesis that the time series is stationary (no unit root) or $I(0)$, Ha: $\alpha<0$. In both tests, if the calculated statistic is less (in absolute terms) than the MacKinnon $(1991,1996)$ critical values the null hypothesis is accepted and there is a unit root in the series. In other words, it means the time series is not stationary. The opposite is true when the calculated statistic is greater than the MacKinnon critical value.

\section{Cointegration and Vector Error Correction Modeling (VECM)}

Most of time series variables are non-stationary individually, but move together over time. In other words the linear combination of non-stationary time series variables may be stationary. In such case, we can say there is cointegration (long run relationship) among variables. Hence testing for cointegration using Engel-Granger two-step procedure (EG) and the Johansen Maximum Likelihood procedure is mandatory.

In the Engle Granger methodology, the residuals from the long-run relationship are tested for stationary to determine whether the variables are cointegrated or not. The DF test could be performed on the residuals to determine their order of integration. If the residual is stationary, then the variables are said to be cointegrated which implies they have long run relationships. The last step in Engel Granger procedure is estimating the error correction model including lagged values of residual as the explanatory variables to see the short run relationships among variables.

Engle Granger procedure suffers from numerous defects. There is only one cointegrating vector even when there are more than one variable involved and categorizes variables as exogenous and endogenous with implication of simultaneity problem. Since our model is multivariate, there is a likelihood of having more than one cointegrating vectors. If there are more than one cointegrating relationships, the Engle-Granger approach would produce inconsistent estimates. Thus, in light of these problems, we prefer the Johansen methodology.

In this study, therefore, we employ vector autoregressive (VAR) based cointegration tests using the methodology developed by Johansen in $(1991,1995)$. The purpose of these cointegration tests is to determine whether the variables in our real exchange rate model are cointegrated or not. The presence of a cointegration relation(s) forms the basis of the vector error correction model (VECM) specification. The Johansen procedure can be formulated as:

Let a vector:

$$
X_{t}=\left[L R E R+L T O T+L G C_{n}+L F E R+L S I+L C I+L N E R\right]
$$

Further assume that the vector has a VAR representation of the form:

$$
X_{t}=z+\sum_{t=1}^{p} \prod_{i} X_{t-i}+\varepsilon_{t}
$$

Where, $X_{t}$ is ( $\left.\mathrm{n} \times 1\right)$ vector of macro-variables of interest (non-stationary variables), $z$ is ( $\left.\mathrm{n} \times 1\right)$ vector of constants, $\Pi$ is $(\mathrm{n} \times \mathrm{n})$ matrix of coefficients and $\varepsilon_{t}$ is $(\mathrm{n} \times 1)$ vector of error terms. In order to use the Johansen test, the VAR (3.9) above needs to be turned into a VECM specification (Brooks, 2002), which may be specified as: 


$$
\Delta X_{t}=z+\sum_{i=1}^{p-1} \Gamma_{i} \Delta X_{t-1}+\prod X_{t-i}+\varepsilon_{t}
$$

Where,

$$
\begin{aligned}
& \Gamma_{i}=-\left[-I-A_{1} \ldots-A_{i}\right], \quad i=1, \ldots, k-1, \\
& \Pi=-\left[-I-A_{1}-\cdots-A_{p},\right.
\end{aligned}
$$

$\mathrm{I}=$ identity matrix (unit matrix), $X_{t}$ is a vector of $\boldsymbol{I}(1)$ variables defined above, $\Delta X_{t}$ are all $\boldsymbol{I}(0)$ variables, $\Delta$ indicates the first difference operator, $\Gamma_{i}$ is a $(\mathrm{nx} \mathrm{n})$ coefficient matrix, $\prod$ is a $(\mathrm{nx} \mathrm{n})$ matrix whose rank determines the number of cointegrating relationships. The Johansen's cointegration test is to estimate the rank of the $\Pi$ matrix (r) from an unrestricted VAR and to test whether we can reject the restrictions implied by the reduced rank of $\Pi$. Regarding this three cases can be distinguished:

I. If $\Pi$ is full rank $(\mathrm{r}=\mathrm{n}), X_{t}$ is stationary (the variables are stationary at levels and no ECM is required).

II. If $\Pi$ is zero rank ( $\mathrm{r}=0)$, all the elements of $X_{t}$ are non-stationary, hence the variables are not co integrated.

III. If $\Pi$ is reduced rank $(\mathrm{r}<\mathrm{n}), r$ is equal to the number of distinct cointegration vectors linking variables in $X_{t}$, as such $\mathrm{r}$ is known as the cointegration rank. Using this last case, the $\prod$ matrix can be decomposed into two $\mathrm{n} \times \mathrm{r}$ matrices, $\alpha$ and $\beta$ such that:

$$
\Pi=\alpha \boldsymbol{\beta}^{\prime}
$$

Where $\alpha$ represents the speed of adjustment matrix, indicating the speed with which the system responds to last period's deviations from the equilibrium relationship and $\beta$ is a matrix of long run coefficients. The rank of a matrix gives the maximum number of independent rows and columns. One should consider here that $\beta^{\prime} X_{t} \sim \mathrm{I}(0)$ and $\alpha$ represents the matrix of weights with which each cointegration vector enters each of the $\Delta X_{t}$ Equation (3.11) can be regarded as a hypothesis of reduced rank of the $\prod$ matrix, showing that it has $r$ cointegrating relationships. We can therefore rewrite equation (3.10) as:

$$
\Delta X_{t}=z+\sum_{i=1}^{p-1} \Gamma_{i} \Delta X_{t-1}+\alpha \beta^{\prime} X_{t-i}+\varepsilon_{t} \text { (3.12) }
$$

The cointegrating vectors $\beta$ have the property that $\beta^{\prime} X_{t}$ is stationary even though $X_{t}$ is itself a vector of non-stationary variables. In order to test for the rank of $\Pi$, there are two issues that should be underlined. The first is determining the appropriate order $(\mathrm{k})$ of the VAR. Brooks (2002) argues that the Johansen test can be affected by the lag length employed in the VECM, thus it is crucial to attempt to select the lag length optimally. By optimally, it is meant that the chosen lag length should produce the number and form of cointegration relations that conform to all the a priori knowledge associated with economic theory. On the other hand, Brooks (2002) argues that economic theory will often have little to say on what an appropriate lag length is for a VAR and how long changes in the variables should take to work through the system. Brooks recommends the use of multivariate versions of the information criteria, which includes the sequential modified likelihood ratio (LR), Akaike information criterion (AIC), Final prediction error (FPE) Schwarz information criterion (SC) and the Hannan-Quinn information criterion (HQ). However, in our experience, these information criteria usually produce conflicting VAR 
order selections. In light of these problems, we will use both the information criteria approach and the a priori knowledge from economic theory to select the appropriate order of the VAR.

The second issue is related to the choice of deterministic assumptions that the Johansen test requires in testing for cointegration. VAR can be estimated based on deterministic trend assumptions like with or without a constant and trend in cointegrating term and with or without a constant in the VAR equations. Here the graphical analysis of the raw data and unit root tests, together with a priori knowledge from economic theory, should assist in selecting the deterministic trend assumption to be used in the Johansen test for cointegration.

Once the appropriate VAR order $(\mathrm{k})$ and the deterministic trend assumption have been identified, the rank of the $\Pi$ matrix can then be tested. There are two likelihood ratio (LR) test statistics for cointegration under the Johansen approach: the trace $\left(\lambda_{\text {trace }}\right)$ and the maximum eigenvalue $\left(\lambda_{\max }\right)$ statistics, which are specified as follows:

$\lambda_{\text {trace }}(r)=-T \sum_{i=r+1}^{n} \ln \left(1-\hat{\lambda}_{\mathbf{i}}\right) \quad 3.13$

$\lambda_{\max }(r, r+1)=-T \ln \left(1-\hat{\lambda}_{\mathrm{r}+1}\right) \quad 3.14$

Where $\hat{\lambda}_{\mathrm{i}}$ is the $\mathrm{i}^{\text {th }}$ estimated eigenvalue and $\mathrm{T}$ is the number of observations. These statistics test the hypothesis that there is at most $r$ cointegrating vectors. The magnitude of the eigenvalues is a measure of how strong the cointegration relation is correlated with a linear combination of the stationary process. The trace statistic sequentially tests the null hypothesis that the number of cointegrating relations is $r$ against the alternative of $\mathrm{k}$ cointegrating relations, where $\mathrm{k}$ is the number of endogenous variables. The maximum eigenvalue conducts separate tests on each eigenvalue and has as its null hypothesis that there are $r$ cointegrating vectors against an alternative of $r+1$ (Brooks, 2002).

To determine the rank of the $\Pi$ matrix the above trace and maximum eigenvalue test statistics are compared to the (nonstandard) critical values from Osterwald-Lenun (1992), which differ slightly from those originally reported by Johansen and Juselius (1990). For both tests, if the test statistic is greater than the critical values, the null hypothesis that there are $r$ cointegrating vectors is rejected in favor of the corresponding alternative hypothesis.

If the trace and maximum eigenvalue statistics yield conflicting results, Johansen and Juselius recommended the examination of the estimated cointegrating vector and basing one's choice on the interpretability of the cointegrating relations. On the other hand Luintel and Khan (1999) show that the traces test is more robust than the maximum eigenvalue statistic in testing for cointegration. The two approaches will be considered in this study when faced with such a problem.

After the number of cointegrating vectors in the model has been identified, a VECM (equation 3.10) can be estimated by specifying the number of cointegrating vectors, trend assumptions used in the previous step and normalizing the model on the true cointegrating relation(s). Thus, a VECM is merely a restricted VAR designed for use with non-stationary series that have been found to be cointegrated. The specified cointegrating relation in the VECM restricts the long run behavior of the endogenous variables to converge to their cointegrating relationships, while allowing for short run adjustment dynamics. The Diagnostic checks test should be made to 
validate the estimated parameters. Among the diagnostic checks residual autocorrelation, normality and heteroscedasticity property of the model would be tested.

The residual serial correlation test of multivariate series for the specified lag order will be checked by Lagrange Multiplier (LM). Harris (1995) argues that the lag order for this test should be the same as that of the corresponding VAR. The test statistic for the chosen lag order $(\mathrm{m})$ is computed by running an auxiliary regression of the residuals $\left(\mu_{t}\right)$ on the original right-hand explanatory variables and the lagged residuals $\left(\mu_{t-m}\right)$. The LM statistic tests the null hypothesis of no serial correlation against an alternative of autocorrelated residuals. To avoid the suspect of whether there is a problem of misspecification the model would be checked by using White heteroscedasticity test. It tests the null hypothesis that the errors are both homoscedastic (no heteroscedasticity problem) and independent of the regressors. The test regression is run by regressing each cross product of the residuals on the cross products of the regressors and testing the joint significance of the regression. The failure of any one or more of the conditions just mentioned above could lead to a significant test statistic. Thus, under the null of no heteroscedasticity and no misspecification, the test statistic should not be significant.

\section{Impulse Response and Variance Decomposition}

Once the determinants of the real exchange rate are identified in a well-specified model, the interesting issues that remain are how the real exchange rate reacts to shocks in any of those determinants. The detail discussion of this topic concerns with which shock is relatively the most important and how long, on average, it will take for the real exchange rate to restore its equilibrium following such shock. To show which of the variables in the model have statistically significant influences on the future values of each of the variables in the system, the usual block F-tests and an examination of causality in a VAR can be used. But these tests will not reveal whether changes in a value of a given variable have a negative or positive influence on the other variables in the system or how long it would take for the effect to work through the system (Brooks, 2002). To provide such information impulse response and forecast error variance decomposition analyses for a VAR process with cointegrated variables will be used.

\section{Impulse Response Analysis}

The responsiveness of the dependent variable in the VAR to shocks to each of the other variables traced out with impulse response analysis. In the context of this paper it shows the sign, magnitude and persistence of real and nominal shocks to the real exchange rate. A shock to a variable in a VAR not only directly affects that variable, but also transmitted to all other endogenous variables in the system through the dynamic structure of the VAR. For each variable from the equations separately, a unit or one time shock is applied to the forecast error and the effects upon the VAR system over time are observed. The impulse response analysis is applied on the VECM and, provided that the system is stable, the shock should gradually die away (Brooks, 2002). In this study the Cholesky orthogonalisation approach is used for performing impulse response analysis. This approach is preferred because, unlike other approaches, it incorporates small sample degrees of freedom adjustments.

\section{Variance Decomposition Analysis}

Variance decomposition analysis measures the proportion of forecast error variance in a variable that is explained by impulses in itself and the other variables. It provides the proportion of the 
movements in the dependent variables that are due to their own shocks versus shocks to the other variables (Brooks, 2002). In other words Variance decompositions performed on the VECM provide some information on the relative importance of shocks to the determinants of the real exchange rate in explaining variations in the real exchange rate. In the variance decompositions the same factorization technique and information used in estimating impulse responses is applied.

\section{Definition of variables and their expected signs}

In this study the variables considered as potential determinants of real exchange rate in the model have the following contextual meanings and expected signs.

Nominal Exchange rate (NER): refers to an official exchange rate which is directly observed from the financial market. It will be used during investigation at its level in logarithm form. The expected sign of the coefficient of nominal exchange rate is positive, because an increase in the nominal exchange rate (devaluation) would result to a depreciation of the real exchange rate.

Capital inflows (CI) - in the context of this paper it represents only capital inflow to the country since there is no significant capital out flow (not net capital inflow). When an economy receives transfer from the rest of the world (capital inflow), current and future domestic expenditure tends to rise, stimulating increased demand for non-traded goods which in turn leads to a rise in the prices of non-traded goods. This will cause the real exchange rate to appreciate.

Share of investment (SI) - indicates the ratio of both foreign direct investment and amount of domestic investment in the country to gross domestic product. It is expected to indicate the influence of total investment in determination of real exchange rate. The sign of this variable depends on the area of investment, whether on tradable or non-tradable goods.

Foreign exchange reserves (FER) - shows the amount of major foreign reserves in National Bank of Ethiopia. But in this study it is the amount of reserve US dollars in the hands of national bank not involved in the transactions excluding gold reserves. In other words it indicates the capacity of country to survive economic shock. An improvement in the stock of foreign exchange reserves is theoretically expected to appreciate the real exchange rate.

Government consumption $\left(\mathbf{G C}_{\mathbf{n}}\right)$ - is the amount of government expenditure particularly on non-tradable goods. Since it is difficult to distinguish the expenditure of government on either tradable or non-tradable, it's proxied by the ratio of total government expenditure to GDP. The decrease in the government consumption of non-tradable would then cause a real exchange rate appreciation and hence, the coefficient for $\mathbf{G C}_{\mathbf{n}}$ is expected to be negative.

Terms of trade (TOT) - represents the purchasing power of a country's exports in terms of imports. By taking into consideration the availability of data we are going to calculate TOT as the ratio of export price index to import price index. The effect of TOT on the real exchange rate depends upon the magnitude of the income effect in relation to the relative price substitution effect. Thus, the sign of the coefficient of TOT cannot be determined a priori since it depends on whether or not the income effect exceeds the substitution effect.

\section{EMPIRICAL RESULTS AND DISCUSSIONS}

The analytical framework and estimation techniques proposed in the previous chapter would be used in this chapter. The questions raised in the first chapter of this study would be answered here. The primary and specific objectives of this paper will be maintained through empirical investigation of this section. In the first section of this chapter the results of stationarity/unit root 
tests will be presented followed by cointegration analysis. The long run relationship and short run dynamics of the model would be discussed in the next section. After the results of diagnostic checks are provided, the results of impulse response analysis and variance decomposition have been presented in the final section of the chapter.

\section{Unit Root Tests and Order of Integration}

In order to achieve a meaningful regression with time series data it is necessary to test the existence of unit roots in the variables. The variables used in the analysis need to be stationary and/or should be cointegrated in order to infer a meaningful relationship from the regression. The unit root test provides the order of integration at which the variables can be stationary. To detect unit roots both informal and formal tests are employed. The informal test for stationarity is the graphical analysis of time series data. A visual plot of the time series is important in such a way that it gives an idea of the trends and stationarity of the data set. Figure 4.1 shows the visual plots of real exchange rate and its potential determinants against time.

From figure 4.1 one can realize that three variables (TO, NER, CI) seem to be trending upward and the other four variables (NER, FER, $\mathrm{GC}_{\mathrm{n}}$, $\mathrm{SI} \%$ ) do not show any trend but highly fluctuates over time. The rest two variables (TOT, TP) have a time variant mean and variance suggesting that they are moving closely around their mean. They might be stationary or closer to stationarity boundary as they seem to be hovering around their means.
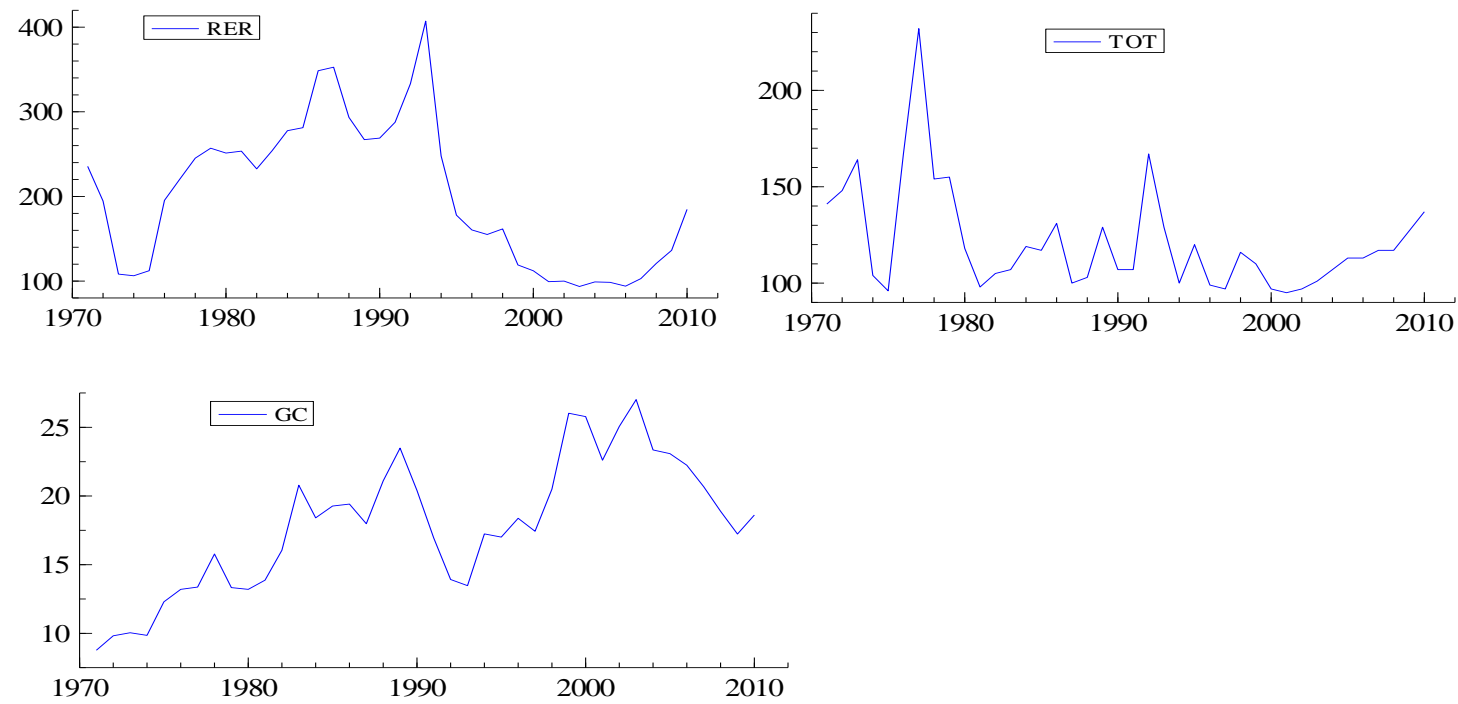

Figure 4.1: Plots of the real exchange rate and its potential determinants, 1971-2010 

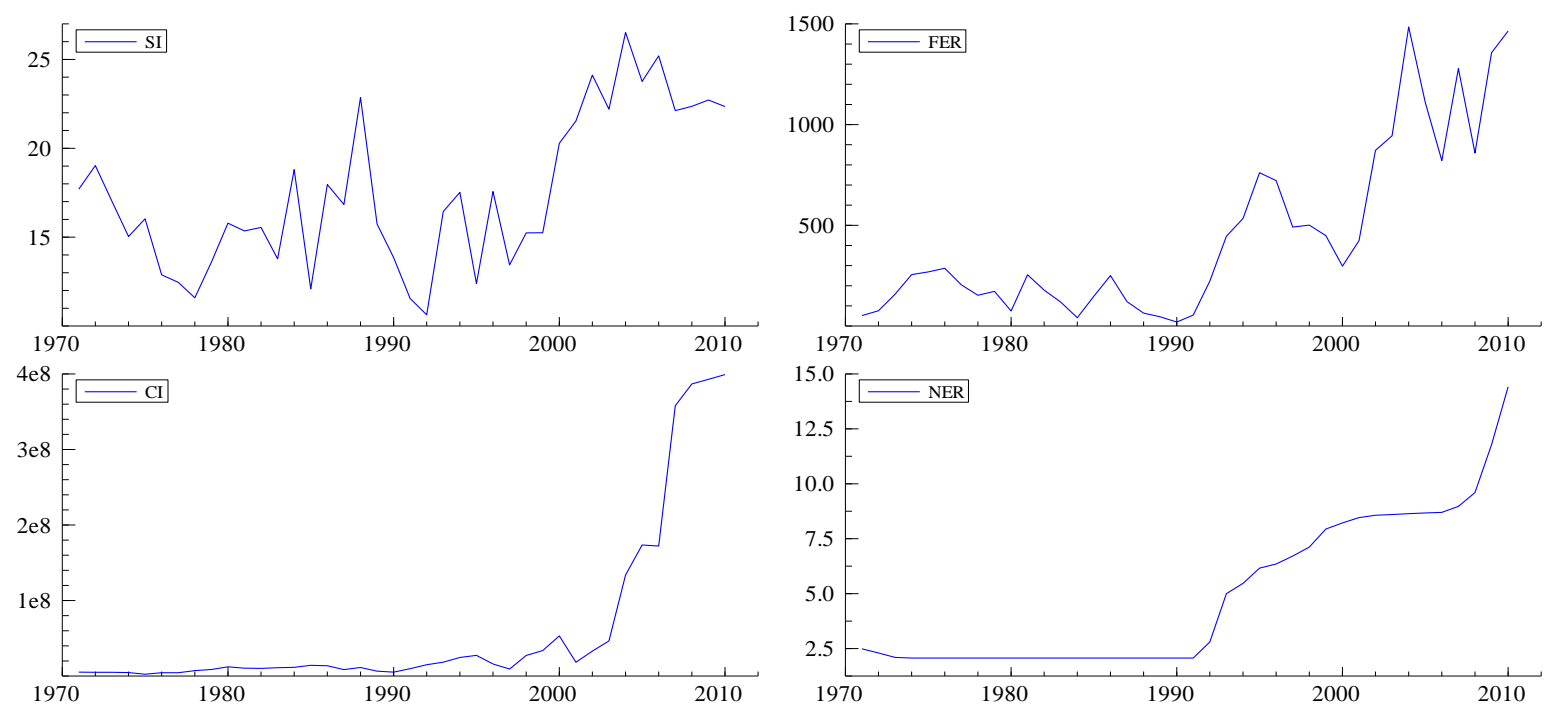

We cannot be deciding whether the variables are stationary or not based on the above graphical analysis alone. To be sure about the stationarity status of these variables following formal hypotheses testing procedure is necessary. In this study the augmented Dickey-Fuller (ADF) test is used as formal testing technique to detect unit roots and the order of integration of the variables. Concerning deterministic trend assumptions constant is included with no trend. Because according to Brooks (2002), the option with no trend and no intercept produced explosive results, while the option with both a trend and intercept made test statistics less significant. But the alternative with constant and no trend provides us robust results. Table 4.1 presents the result of the unit root test statistics for the variables of interest in our empirical analysis.

Table 4.1: Results of unit root tests

\begin{tabular}{|c|c|c|}
\hline \multicolumn{3}{|c|}{ ADF Test } \\
\hline \multicolumn{2}{|c|}{$\begin{array}{c}\text { The null hypothesis: Ho }=\alpha=(\rho-1)=0 ; \\
\text { Against }\end{array}$} & $1^{\text {st }}$ difference \\
\hline Variable & Level & -4.770 \\
\hline RER & -1.577 & -6.969 \\
\hline TOT & -2.442 & -10.234 \\
\hline SI\% & -1.260 & -5.514 \\
\hline GC & -2.184 & -5.253 \\
\hline FER & -0.754 & -5.334 \\
\hline CI & 1.642 & -6.584 \\
\hline NER & 1.334 & \\
\hline \multicolumn{2}{|c|}{ Test critical values: $1 \%=-3.618$} \\
\end{tabular}


The unit root tests reveal that all the variables are non-stationary at levels. When the test is applied to first differences of all variable, they become stationary and hence the variable are considered as I(1) process.

\section{Test for Cointegration: Test for Number of Cointegration Vectors}

We have already identified the order of integration of each variable that enters the specified model of real exchange rate determination. All the variables are cointegrated of order one. The next step is to estimate the long run relationship between Ethiopia's real exchange rate and it determinants using the Johansen maximum likelihood method. This method is selected because it produces consistent estimates of the long run parameter, which could be tested using likelihood ratio (LR) statistics. The method also obtains estimates of $\alpha$ and $\beta$ using the reduced rank regression.

Different researchers (for example: Edwards, 1994; Aron et al, 1997 and Takaendesa, 2006) face some difficulties during testing for cointegration using the full real exchange rate model. In most studies, it has produced too many cointegrating relationships which are difficult to interpret. Takaendesa (2006) argues that the main difficulty of cointegrating vectors including large number of variables is their interpretation. An alternative option to deal with such problem is to estimate the simplified model. To avoid the bias of omitted variables while model simplification pairwise correlation matrix would be used to guide the variables selection. The following table 4.2 presents the pairwise correlation of all variables in the model.

Table 4.2: Pairwise correlation matrix

\begin{tabular}{|c|ccccccc|}
\hline & LRER & LTOT & LGC & LSI & LFER & LCI & LNER \\
\hline LRER & 1.0000 & 0.27842 & -0.27465 & -0.56198 & -0.62980 & -0.46750 & -0.64630 \\
LTOT & 0.27842 & 1.0000 & -0.48927 & -0.35713 & -0.16252 & -0.18850 & -0.29950 \\
LGC & -0.27465 & -0.48927 & 1.0000 & 0.39805 & 0.34139 & 0.54022 & 0.54744 \\
LSI & -0.56198 & -0.35713 & 0.39805 & 1.0000 & 0.47690 & 0.65245 & 0.61877 \\
LFER & -0.62980 & -0.16252 & 0.34139 & 0.47690 & 1.0000 & 0.74121 & 0.84042 \\
LCI & -0.46750 & -0.18850 & 0.54022 & 0.65245 & 0.74121 & 1.0000 & 0.84892 \\
LNER & -0.64630 & -0.29950 & 0.54744 & 0.61877 & 0.84042 & 0.84892 & 1.0000 \\
\hline
\end{tabular}

The above table reveals that LSI, LFER and LNER are highly correlated with LRER. On the other hand LTOT, LGC and LCI are the variables less correlated with LRER. To get the meaningful result and include as many variables as suggested by theory, the risk of omitted variable bias should be minimized. From table 4.2 there are no variable shows any sign of multicollinearity problem. . Hence the real exchange rate model could be estimated with the all explanatory variables.

In order to proceed with Johansen cointegration technique the lag order and deterministic trend assumption for the VAR should be specified. During unit root test the assumption of including constant but no trend was accepted. Therefore, the deterministic trend assumption for the VAR excludes trend and includes constant. For the selection of the lag order of the VAR, information criteria approach and theoretical facts are used as the guide. The following table shows the lag length chosen by different information criteria. 
Table 4.3: VAR Lag Order Selection Criteria

\begin{tabular}{ccccccc}
\hline \hline Lag & LogL & LR & FPE & AIC & SC & HQ \\
\hline \hline 0 & -1447.31 & NA & $7.3 \mathrm{e}+26$ & 78.8814 & 79.4039 & 79.0656 \\
1 & -1338.77 & 217.07 & $1.5 \mathrm{e}+25^{*}$ & $74.9607 *$ & $77.0505^{*}$ & $75.6975^{*}$ \\
2 & -1305.49 & 66.572 & $2.1 \mathrm{e}+25$ & 75.1074 & 78.7646 & 76.3967 \\
3 & -1271.48 & $68.005^{*}$ & $4.0 \mathrm{e}+25$ & 75.2154 & 80.44 & 77.0573 \\
\hline \hline
\end{tabular}

* indicates lag order selected by the criterion

LR: Sequential modified LR test statistic (each test at 5\% level)

FPE: Final prediction error

AIC: Akaike information criterion

SC: Schwarz information criterion

\section{HQ: Hannan-Quinn information criterion}

Table 4.3 reveals that while FPE, AIC, SC and HQ information criteria chooses 1 lag order, LR selects 3 lag order for the VAR. Therefore, the information criteria provides the conflicting lag orders as expected. Brooks (2002) attributes this problem to a small sample bias. However, from the theoretical point of view since the data is annual data 1 lag order is a reasonable lag order selection for the VAR. Thus, the Johansen cointegration test conducted under the assumption of no trend but a constant in the series and 1 lag for the VAR. Most of the time the trace and maximum eigenvalues statistics might yield conflicting results. To deal with this problem Johansen (1990) recommend basing on one of them to identify the number of cointegration vectors. But Khan (1999), shows that the trace test is more robust than the maximum eigenvalue statistic in testing for cointegration. Hence to avoid the confusing result of estimation in this paper only the output of trace eigenvalue would present. Table 4.4 below shows the cointegration test results for the real exchange rate model based on trace eigenvalue statistics.

Table 4.4: Result of the Test for the Number of Cointegrating Vectors

\begin{tabular}{|c|c|c|c|c|}
\hline H0: rank $=r$ & Eigenvalue & $\begin{array}{c}\text { Trace } \\
\text { test }\end{array}$ & $\begin{array}{l}5 \% \text { critical } \\
\text { value }\end{array}$ & pvalue \\
\hline 0 & 0.66490 & 134.04 & 124.24 & {$[0.013] *$} \\
\hline 1 & 0.60893 & 91.405 & 94.15 & [0.094] \\
\hline 2 & 0.48195 & 54.788 & 68.52 & {$[0.431]$} \\
\hline 3 & 0.35999 & 29.139 & 47.21 & {$[0.762]$} \\
\hline 4 & 0.19679 & 11.734 & 29.68 & {$[0.937]$} \\
\hline 5 & 0.077888 & 3.1876 & 15.41 & {$[0.950]$} \\
\hline 6 & 0.00064420 & 0.025132 & 3.76 & {$[0.874]$} \\
\hline
\end{tabular}

\section{Diagnostic Tests:}

Vector Portmanteau (5): 244.621

Vector AR 1-2 test: $\quad F(98,78)=1.3711[0.0740]$

Vector Normality test: $\mathrm{Chi}^{\wedge} 2(14)=26.374$ [0.0232]*

Vector hetero test: $\quad \mathrm{Chi}^{\wedge} 2(392)=404.17$ [0.3250] 
The above table shows that the null hypothesis of no cointegrating vectors is rejected but the null hypothesis that there are at most 1 cointegrating vector cannot be rejected. This is confirmed by comparing the trace eigenvalues $\left(\lambda_{\text {trace }}\right)$ with the given critical values. Regarding diagnostic tests, there is no problem of auto correlation and heteroscedasticity, but it indicates vector normality problems. However, according to Enders (1995), since the main purpose of normality tests is for checking hypothesis about the population parameter using confidence intervals, the existence of normality problem does not affect the estimations of coefficients and $t$ - values. If the sample size were getting larger the normality problem can be easily removed and the distribution approaches normal.

Once it is statistically supported that there is one cointegrating vector, the first column of the $\alpha$ matrix and first row of the $\beta$ ' matrix are relevant. The speed of adjustment could be represent by $\alpha_{11}(-0.26)$ with expected sign and statistically significant. However, which of the variables is explained as a linear combination of others is not known from this result. We need to undertake weak exogeneity tests for all variables using the first column of $\alpha$ - coefficients.

Table 4.5: Results of Cointegration analysis Standardized $\beta$, Eigenvectors

\begin{tabular}{|c|c|c|c|c|c|c|}
\hline LRER & LTOT & LGC & LSI & LFER & LCI & LNER \\
\hline 1.0000 & -0.67380 & -1.3153 & 2.2580 & 0.14009 & 0.46528 & -1.1703 \\
\hline-34.654 & 1.0000 & 25.168 & 43.140 & -1.5311 & -1.9891 & -34.007 \\
\hline 0.51017 & 1.3527 & 1.0000 & 1.2614 & 0.42636 & -0.29798 & -0.19202 \\
\hline-0.41453 & 6.8639 & 1.3511 & 1.0000 & -2.1153 & 0.091361 & 2.8888 \\
\hline-4.4139 & 11.341 & -11.158 & -2.1208 & 1.0000 & -0.35532 & -1.2927 \\
\hline 0.90486 & -0.39510 & -1.2437 & 1.5614 & 0.10832 & 1.0000 & 0.66452 \\
\hline-2.1711 & 0.50873 & -2.8737 & 2.0893 & 0.19807 & 0.66452 & 1.0000 \\
\hline
\end{tabular}

Standardized $\alpha$ coefficients

\begin{tabular}{|l|l|l|l|l|l|l|l|}
\hline LRER & -0.25696 & 0.0028526 & -0.081709 & -0.021281 & 0.0021081 & 0.0026534 & 0.0033420 \\
\hline LTOT & 0.035128 & 0.0020163 & -0.17119 & -0.041589 & -0.010629 & -0.0099306 & 0.0020137 \\
\hline LGC & 0.092225 & -0.0011557 & 0.033962 & -0.026514 & 0.0062331 & -0.0052753 & 0.00023745 \\
\hline LSI & -0.14629 & -0.0047166 & -0.049363 & -0.012197 & 0.0026217 & -0.032970 & -0.0034896 \\
\hline LFER & 0.19522 & -0.0012734 & -0.86421 & 0.11506 & 0.0051792 & -0.015192 & 0.0065603 \\
\hline LCI & -0.029183 & -0.0014180 & 0.063136 & 0.018882 & -0.0037849 & -0.14209 & 0.0088962 \\
\hline LNER & -0.051963 & -0.0036853 & -0.046638 & 0.0029580 & -0.00090515 & 0.013166 & 0.0018581 \\
\hline
\end{tabular}

A test for weak exogeneity is conducted by imposing a zero restriction on the $\alpha$ coefficients of the first column using likelihood ratio (LR) test. According to Johansen (1992), if the speed of adjustment coefficients ( $\alpha_{i}$ 's) in the cointegration analysis approach zero, then the corresponding variables can be considered weakly exogenous. The significance of the hypothesis of weak exogeneity in empirical analysis is that, if the variables are weakly exogenous, then it is legitimate to abandon the multivariate model and perform the analysis using the single equation 
approach by conditioning on these variables This test does not reject the null hypothesis if all the variables are weakly exogenous.

Table 4.6: Test for zero- restrictions on $\boldsymbol{\alpha}$-coefficients (the Weak Exogeneity Test)

\begin{tabular}{|c|c|c|c|c|c|c|c|}
\hline & LRER & LTOT & LGC & LSI & LFER & LCI & LNER \\
\hline$\alpha$ - Coefficients & -0.25696 & 0.035128 & 0.092225 & -0.14629 & 0.19522 & -0.029183 & -0.051963 \\
\hline LR-test $\chi^{2}(1)$ & 4.7436 & 0.21103 & 2.7010 & 1.5617 & 0.75669 & 0.049749 & 0.52472 \\
\hline Probability & $0.0294^{*}$ & 0.6460 & 0.1003 & 0.2114 & 0.3844 & 0.8235 & 0.4688 \\
\hline
\end{tabular}

* Indicates the rejection of null hypothesis.

The rejection of weak exogeneity hypothesis implies that LRER is endogenous variable. The tests indicate that the null hypothesis, the variable is weakly exogenous, is rejected for the real exchange rate at 5 percent significance level. Terms of trades, government consumption of nontradable goods, share of investments, foreign exchange reserves, capital inflows and nominal exchange rates are accepted to be weakly exogenous.

\section{The Estimation of Long-Run Model}

In determining the variables which are uniquely constitute the cointegrating vectors, the significance of the long-run variables must be tested by imposing a zero restrictions on each respective coefficient. The results of test for zero restrictions on the first row of vector $\beta$ coefficients are reported in the following table

Table 4.7: Test for zero- restrictions on $\boldsymbol{\beta}$ - coefficients (the Long-Run Parameters)

\begin{tabular}{|c|c|c|c|c|c|c|c|}
\hline & LRER & LTOT & LGC & LSI & LFER & LCI & LNER \\
\hline$\beta^{\prime}$ - Coefficients & 1.0000 & -0.67380 & -1.3153 & 2.2580 & 0.14009 & 0.46528 & -1.1703 \\
\hline LR-test $\chi^{2}(1)$ & 4.2245 & 1.1961 & 0.026611 & 6.6959 & 6.1178 & 14.685 & 1.3712 \\
\hline Probability & $0.0398^{*}$ & 0.2741 & 0.8704 & $0.0097 * *$ & $0.0134^{*}$ & $0.0001^{* *}$ & 0.2416 \\
\hline
\end{tabular}

** Denotes significance at 1 percent level

* Denotes significance at 5 percent level

Having attained a single co-integrating vector using $\lambda_{\text {trace }}$ statistics, and the real exchange rate being endogenous variable, we can express LRER as a linear combination of the explanatory variables. Thus, the relevant linearly dependent equation models with the estimates of the longrun coefficients can be formulated as:

$$
\begin{gathered}
L R E R=0.67 L T O T+1.32 L G C-2.26 L S I-0.14 L F E R-0.47 L C I \\
+1.17 L N E R
\end{gathered}
$$

As indicated above the signs of the coefficients are consistent with theoretical predictions. The likelihood ratio test statistics using $\chi^{2}-$ distribution indicate that the coefficients of share of investment and capital inflow are significant at 1 per cent level, while the 
coefficient of foreign exchange reserve is significant at 5 percent level. But the coefficients of terms of trade and nominal exchange rates are, statistically insignificant. In other words in Ethiopian economy foreign exchange reserve, share of investment and capital inflow had long run effect on real exchange rate. However, terms of trade and nominal exchange rate had no impact on real exchange rate in the long run.

The coefficient on government consumption for the real exchange rate is positive and significant. Changes in government expenditure affects real exchange rate through two channels. We first assume that an increase in government expenditure on non-tradable is financed through an increase in public debt. Then the first effect of an increase in government expenditure would be an increase in the price of non-tradable goods, leading to an appreciation of real exchange rate. However, the financing of the increased spending would require increased government borrowing. This would reduce income, causing a reduction in the demand for non-tradable commodities in the private sector, reducing the price of non-tradable goods and causing a depreciation of the real exchange rate. The overall effect would depend on the relative dominance of the income or substitution effects. In the estimation of this paper the income effect dominate the substitution effect as one percent increase in government expenditure on non-traded goods would leads to 1.32 percent depreciation in real exchange rate. Even though the detailed data on the composition of government consumption could not obtain, a general review of some statistics reveals that a large percentage of government consumption consists of wages and salaries, followed by recurrent departmental charges. Other researchers on developing countries (Elbadawi, 1997 and Edwards, 1989) have been also obtained the same results with the empirical finding of this paper.

The coefficient on investment share found for the real exchange rate is negative and significant. It suggests that gross fixed capital formation has affected more the relative price of non-tradable commodities. Since most of the investment is in buildings that are constructed using locally produced cement and materials, this might have contributed in increasing the price of nontradable goods and hence appreciating the real exchange rate. One percent increase in share of investment will appreciates Ethiopian birr in real terms by 2.26 percent. The implication is that the demand side effect of investments has been stronger than the supply side effect of investments.

The coefficient on central bank reserves is negative and significant. It indicates that an increase in central bank reserves appreciates the real exchange rate for. This is consistent with finding of Aron et al (1997) in the case of South Africa.

The coefficient of net capital inflow is negative as suggested by theory and is statistically significant. The negative sign of the coefficient indicate that an increase in foreign exchange supply tends to appreciate the real exchange rate. An inflow of capital leads to an increase in foreign exchange, hence leading to an increase in foreign reserves. This increase in foreign reserves may require a decrease in domestic credit in order to maintain the money supply and this occurs through an appreciation of the exchange rate. This finding is consistent with other empirical findings by some economists such as Edwards (1986) in which he investigated the role of capital inflows in the process of real exchange rate determination in Chile showed that an 
increase in net capital inflow is associated with a real appreciation and Greene (1993) also obtained comparable results for Sub-Saharan African countries.

\section{Estimation of the Error-Correction Model}

Having already obtained the long-run model and estimated the coefficients, the next step will be estimation of coefficients of the short-run dynamics that have important policy implications. Hence, an error correction model will be estimated which incorporates the short term interactions and the speeds of adjustment towards long run model. In the error correction model, the shortrun disequilibrium is approximated by the first lag of the estimated long-run linear combination. The procedure adopted for estimation is the Hendry's approach of general to-specific modeling. In this approach a large model is estimated first which includes as many of the explanatory variables and their lags as possible. Then all insignificant explanatory variables are continuously dropped until a parsimonious model with few explanatory variables but acceptable in terms of significance, economic interpretation and diagnostic validity is obtained. It is very important to specify how short run adjustment of the variables took place and base fertile ground for policies analysis \& implementations.

Various diagnostic tests were carried out in order to determine the robustness of the real exchange rate model. The results show that the residuals of the model are normal, there is no autocorrelation problem, there is no heteroscedasticity problem and there is no auto regressive conditional heteroscedasticity.

Table 4.8: Estimation results of VECM

\begin{tabular}{|c|c|c|c|}
\hline \multicolumn{4}{|c|}{ Dependent Variable: DLRER } \\
\hline Variables & Coefficient & t-prob. & \multirow{2}{*}{$\begin{array}{l}\text { Diagnostic Tests } \\
\text { AR 1-2 test: } F(2,33)=0.95631[0.3947]\end{array}$} \\
\hline DLTOT & 0.270823 & 0.030 & \\
\hline DLCI_1 & -0.136236 & 0.007 & ARCH 1-1 test: $F(1,33)=0.47997[0.4933]$ \\
\hline DLNER & 0.657783 & 0.007 & Normality test: $\chi^{2}(2)=5.3390[0.0693]$ \\
\hline ECM_1 & -0.309579 & 0.000 & Hetero test: $\quad F(6,28)=0.57063[0.7501]$ \\
\hline \multicolumn{3}{|l|}{$\begin{array}{l}\mathrm{R}^{2}=0.54 \\
\mathrm{DW}=1.4\end{array}$} & $\begin{array}{ll}\text { Hetero-X test: } & F(9,25)=0.58049[0.8003] \\
\text { RESET test: } & F(1,34)=1.2828[0.2653]\end{array}$ \\
\hline
\end{tabular}

The coefficient of the vector error correction term is significant with expected sign and reasonable magnitude $\left(E C M \_1=-0.31\right)$. The coefficient of the error correction term of the real exchange rate model is negative and less than one. This result ensures that real exchange rate convergences to its long run equilibrium. However, the speed of adjustment of the real exchange rate to its own long run equilibrium is moderate as shown by the adjustment coefficient. Every year just over 30 percent of the disequilibrium in real exchange rate is adjusted. Thus, it takes more than three years to adjust fully.

The positive and significant effect of the terms of trade on the real exchange rate indicates that the substitution effect dominates the income effect. In other words the positive and significant term of trade implies that an increase (improvement) in the TOT would cause a depreciation of the RER. The substitution effect may have been on the supply side, in which case an improvement in the terms of trade may have relaxed the foreign exchange constraints on intermediate inputs in the production of non-tradables. This in turn helped the producers to 
increase the supply of non-tradable goods, and hence lowering the price of non-tradables. This resulted in the depreciation in the real exchange rate indices. This result is consistent with the empirical results of Elbadawi (1997) who found that the substitution effect dominated the income effect in Côte d'Ivoire, Ghana and India.

The result of the error correction model shows that nominal exchange rate is significant and has positive relationship with real exchange rates. This implies that in Ethiopia depreciation of nominal exchange rate leads to a depreciation of the real exchange rate.

The one period lag of capital flow has negative effect on the real exchange rate though the contemporaneous value is insignificant in the model. This implies that an increase in capital flow to Ethiopia in a particular year, appreciates the real exchange rate in the following year.

\section{Impulse Response Analysis}

Impulse response analysis reveals a wealth of information on dynamic effects that is missing in both static studies and those dynamic studies that do not employ these techniques. Figure 6.2 presents the results from the impulse response analysis performed on the VECM regression. In this figure since the study focuses on the determinants of the real exchange rate, only the responses of the real exchange rate to shocks in its determinants are presented. These impulse response functions show the dynamic response of the real exchange rate to a one-period standard deviation shock to the innovations of the system. Additionally, they indicate the directions and persistence of the response to each of the shocks for five years.

\section{Response to Cholesky One S.D. Innovations}
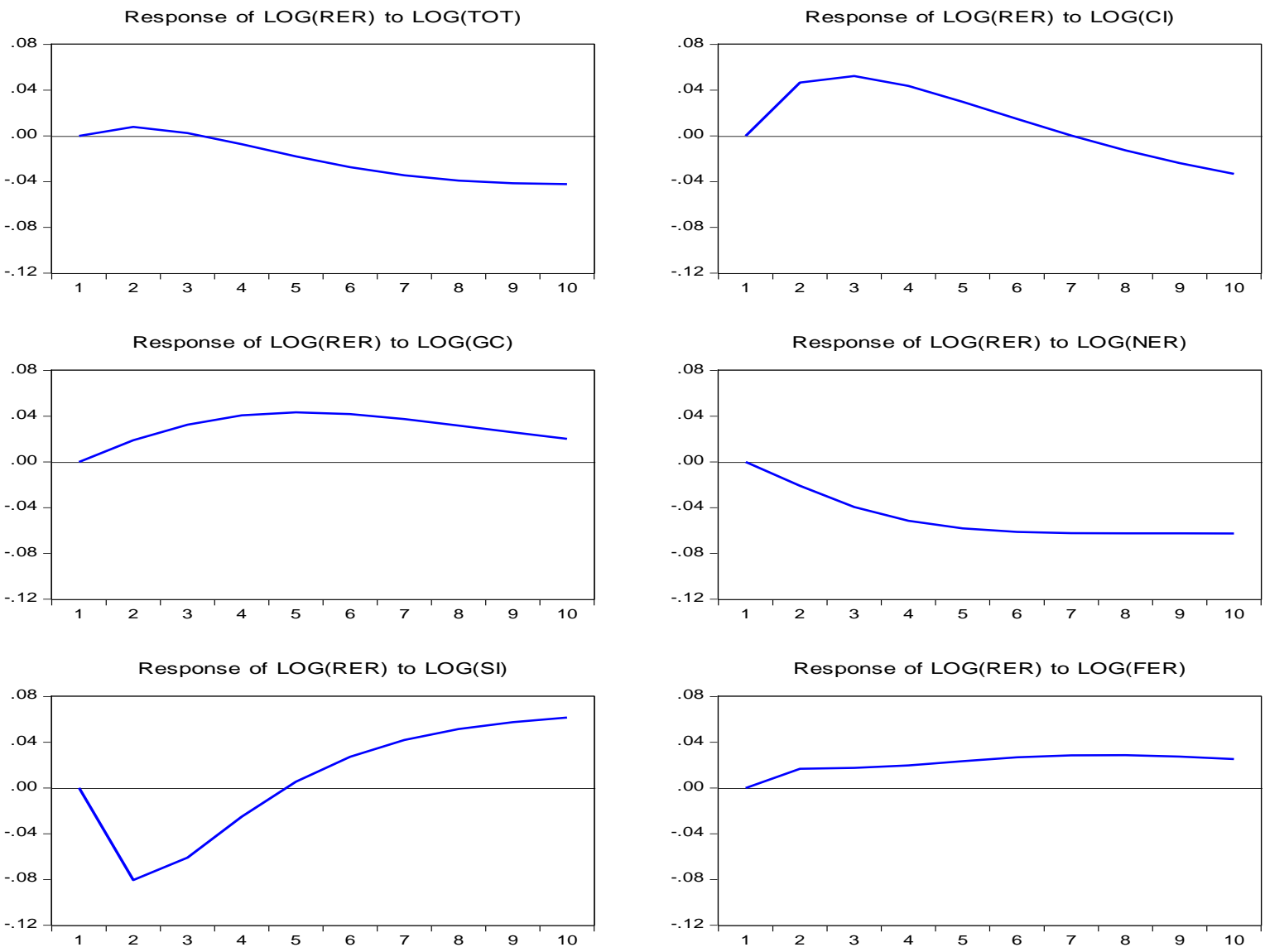

Figure 6.2: Impulse Responses of the Real Exchange Rate 
For the most part, the impulse response functions have the expected pattern and confirm the results from the short run relationship analysis. Shocks to three variables are significant and are persistent, while Shocks to the other three variables are non-linear and are transitory. A oneperiod standard deviation shock to LCI appreciates the real exchange rate but the impact dies off and even starts to depreciate LRER after some years. A shock to LGC has a marginal appreciation effect on the real exchange rate but it is also transitory. A one period standard deviation shock to LSI depreciates the real exchange rate by more than 8 percent, but also gradually levels off in about 5 years. The Variables that have persistent and significant effects on the real exchange rate are the terms of trade, nominal exchange rate and foreign exchange reserves. The response of the real exchange rate to a one-period shock to nominal exchange rate and terms of trade is a continued depreciation. This result implies that expansionary monetary policy depreciates the real exchange rate in the short run. Lastly, the response of the real exchange rate shocks to foreign exchange reserve is marginal appreciation. Thus, the shocks of terms of trade, nominal exchange rate and foreign exchange reserves have a significant impact on the real exchange rate in the short run. However, all the other variables have only a transitory effect on the real exchange rate.

\section{Variance Decomposition Analysis}

Variance decomposition analysis provides a way of determining the relative importance of shocks to each of the determinants of the real exchange rate in explaining variations in the real exchange rate. The following table shows the proportion of the forecast error variance in the real exchange rate.

Table 6.7: Variance decomposition of the real exchange rate

\begin{tabular}{lllllllll}
\hline \hline Period & S.E. & LRER & LTOT & LCI & LGC & LNER & LSI & \multicolumn{2}{l}{ LFER } \\
\hline \hline 1 & 0.137696 & 100.0000 & 0.000000 & 0.000000 & 0.000000 & 0.000000 & 0.000000 & 0.000000 \\
2 & 0.205566 & 84.87838 & 0.041538 & 0.200293 & 0.426148 & 0.435839 & 13.38266 & 0.635139 \\
3 & 0.251505 & 61.71375 & 0.896860 & 7.590053 & 1.748224 & 6.555348 & 21.06771 & 0.428055 \\
4 & 0.281792 & 49.32475 & 3.270686 & 10.83277 & 2.750359 & 12.93102 & 20.51700 & 0.373416 \\
\hline \hline
\end{tabular}

The above table reports only the variance decomposition in the real exchange rate and analysis the relative importance of each of its determinants in influencing its movements, because the interest is to know the movements of the real exchange rate following shocks to itself or its determinants.

As Brooks (2002) suggests, in the first year all of the variance in the real exchange rate is explained by its own shocks. For the second year a head forecast error variance the real exchange rate itself explains about 85 per cent of its variation, while all its determinants explain only the remaining 15 percent. Out of this 15 percent the share of investment explain about 13 percent, foreign exchange reserve about 0.6 percent and nominal exchange rate 0.4 percent, while the remaining variables do not significantly contribute to the variation in the real exchange rate. 
In the fourth year the real exchange rate explains about 49 percent of its own variation, while its determinants explain the remaining 51 percent. The influence of share of investment increases substantially to about 21 percent, explaining the largest component of the 51 percent variation in the real exchange rate that is explained by its determinants. Thus, share of investment explains the largest component of the variation in the real exchange rate followed by nominal exchange rate and capital inflow which is similar with results from the impulse response analysis.

\section{CONCLUSIONS}

This study analyzed the relationship between the real exchange rate and its theoretical determinants and the dynamic adjustment of the real exchange rate following shocks to those determinants. The importance of real exchange rate in the country's economic stability was briefly reviewed in this study. In this paper an extensive review of the literature on the real exchange rate and its determinants, a background of the exchange rate system in Ethiopia and on data availability, an empirical model that links the real exchange rate to its potential determinants was specified. The variables included as potential determinants in this model are terms of trade, foreign exchange reserve, nominal exchange rate, share of investment, capital inflow, and government consumption of non-tradable goods.

The Johansen cointegration and error correction methodology was preferred to the other techniques to determine both the long and short run determinants of the real exchange rate. The application of this technique started by analyzing the time series properties of the data employing both informal and formal tests for stationarity. All variables were found to be integrated of the same order, $I(1)$. The test of specified model indicates that there is cointegration between the real exchange rate and its determinants. The parameter estimation of the long and short run relationships of real exchange rate and its determinants were provided in cointegration and vector error correction model methods. Share of investment, foreign exchange reserve, capital inflow and government consumption of non-tradable goods were the variable that have a long run relationship with the real exchange rate. An increase of foreign exchange reserve, capital inflow and share of investment all appreciate the real exchange rate in the long run, while high government consumption of non-tradable goods is associated with a real depreciation of the real exchange rate.

The coefficient of speed of adjustment in the real exchange rate following a shock in the system was found in vector error correction model regression. The estimate of this parameter indicates that about 30 percent of the variation in the real exchange rate from its equilibrium level is corrected within a year.

The regression result of VECM reveals that terms of trade, nominal exchange rate, and one period lag of capital flow were the variables significantly affects the real exchange rate in the short run. The model shows that while both increase in terms of trade and depreciation of nominal exchange rate depreciates real exchange rate, an increase in capital flow to Ethiopia in a particular year appreciates the real exchange rate in the following year. The impulse response and variance decomposition analysis also shows a better picture of the short run dynamics. The impulse response analysis provided evidence that the terms of trade, nominal exchange rate, capital inflow and share of investment have a significant impact on the real exchange rate in the 
short run. Shocks to these variables have persistent effects on the real exchange rate. The analysis of variance decompositions of the real exchange rate are largely similar to those from the impulse response analysis and reveal that the fundamentals variables explain some of the variations of the real exchange rate. The terms of trade, nominal exchange rate, capital inflow and share of investments are the variables significantly explain the variation in the real exchange rate.

Generally, the regression results of both long run and short run models mostly suggest that the fluctuations of real exchange rates are predominantly responses to monetary policies shocks rather than fiscal policy shocks.

\section{POLICY IMPLICATIONS}

This study had tried to identify the major determinants of real exchange rate in Ethiopian both in the short run and the long run. The policy implications that can be derived from this empirical study are:

- To the extent that capital inflow appreciates the real exchange rate, there is need for the creation of an enabling environment that encourages investment in the tradable goods sector, rather than the non-tradable goods sector. This can be done by reforming the agricultural and industrial sectors of Ethiopia so that they will attract investment for export purpose and reforming the mining sector for increased investment.

\section{REFERENCES}

[1] Aron, et al, (1997), "Determinants of the Real Exchange Rate in South Africa”, Centre for the Study of African Economies, WPS/97-16, CSAEPublishing, and Oxford.

[2] Baffes, et al, (1999), "Single- Equation Estimation of the Equilibrium Real Exchange Rate”, in Hinkle.

[3] Beatrice Kalinda Mkenda (2001), "Long-run and Short-run Determinants of the Real Exchange Rate in Zambia." Research paper 2001/40.

[4] Black, Stanley, W., (1994), "On the Concept and Usefulness of the Equilibrium Rate of Exchange”, in Williamson, John (ed.), Washington DC.

[5] Copeland, L. S., (1994). "Exchange rates and international finance." Workingham, England: Addison-Wesley.

[6] Degefa D. (2001), "The Parallel Foreign Exchange Market and Macroeconomic Performance in Ethiopia. "AERC Research Paper 107.

[7] Edwards, S. (1989), Real Exchange Rates, Devaluation and Adjustment: Exchange Rate Policy in Developing Countries, MIT Press, Cambridge, Massachusetts

[8] Elbadawi, I., (1994). “Estimating long-run equilibrium exchange rates.”Washington. Institute for International Economics.

[9] Fosu, K.Y (1992). "The Real Exchange Rate and Ghana's Agricultural Exports", AERC Research paper, no.9 October 1992.

[10] Geda, A. (2006), "The Structure and Performance of Ethiopia's Financial Sector in the Pre- and Post-Reform Period with a Special Focus on Banking." WIDER Research Paper 2006/112. 
[11] Giancarlo Gandolfo (2002),"International financial and Open Economy macroeconomics. "Springer printing press: Heidelberg.

[12] Gujarati, D. N., (2003), "Basic econometrics", fourth edition New York: McGraw-Hill Inc.

[13] Harris R. (1995), Using Cointegration Analysis in Econometric Modeling. Printce hall.

[14] Harry A. Sackey (2001). "External aid inflows and the real exchange rate in Ghana."AERC Research Paper 110, Nairobi.

[15] Jerome L. Stein, Polly Reynolds Allen, and Associates (1995). "Fundamental Determinants of Exchange Rates." Clarendon Press, Oxford

[16] John E. Floyd (2010). "Interest Rates, Exchange Rates and World Monetary Policy", Springer, Toronto.

[17] Kombe Oswald Mungule (2004), "The determinants of the real exchange rate in Zambia". AERC, Research Paper 146.

[18] Luintel, K. B. and khan, M., 1999, "A quantitative reassessment of the finance-growth nexus: evidence from a multivariate VAR." Journal of Development Economics 60.

[19] Lütkepohl, H., 1991, "Introduction to multiple time series analysis”. New York: SpringerVerlag.

[20] Miyakoshi, T., (2003). "Real exchange rate determination: empirical observations from East-Asian countries. "Empirical Economics28: 173-180.

[21] Montiel, P. J. (1999). "Determinants of the long-run equilibrium real exchange rate." New York: Oxford University Press.

[22] Montiel, P. J., (2003). "Macroeconomics in emerging markets." Cambridge: Cambridge University Press.

[23] Muhammad Zakaria and Ahmed Bilal Ghauri (2011). "Trade Openness and RealExchange Rate: Some Evidence from Pakistan. "Institute of Development Economics, Islamabad.

[24] Opoku Afari, M. (2004), "Measuring the Real Effective Exchange Rate in Ghana." CREDIT Research Paper 04/11.

[25] Pedro M. G. Martins (2009), "Do Capital Inflows Hinder Competitiveness?" CREDIT Research Paper 10 (07).

[26] Peter Takaendesa (2006), "The Behavior and Fundamental Determinants of the Real Exchange Rate in South Africa. "Rhodes University.

[27] Pierre-Richard Agenor and Peter J. Montiel (2008). "Development Macroeconomics." 3rd Ed, Princeton University Press, Woodstock.

[28] Rehana. S, Usman. A, and Zafar. M (1996), "Exchange Rate Determination in Pakistan. "The Pakistan Development Review, 35(4),683-692.

[29] Robert Dauda Korsu and Samuel Jamiru Braima (2007). "the determinants of the real exchange rate in Sierra Leone." Fourah Bay College, University of Sierra Leone.

[30] Ronald MacDonald (2007). "Exchange Rate Economics Theories and evidence", Rutledge printing press, New York.

[31] Stefan Dercon and Lulseged Ayalew (1994), Coffee Prices and Smuggling in Ethiopia, Ethiopian Journal of Economics, Vol. 3, No.2. 